\title{
Volumetric Efficiency Evaluation of the Use of Refrigerants R445a, R515a, R456a, ND, and R516a with Low GWP Instead of R134a
}

\section{Ümit İSKKAN ${ }^{1}$, Mehmet DİREK $^{2}$, Cemil KOYUNOĞLU²* ${ }^{*}$, Fikret YÜKSEL ${ }^{2}$}

\begin{abstract}
In this study, the performance of different refrigerants (with low GWP value) depending on thermophysical properties in the cooling system was evaluated. The cooling capacities of R134a, R445a, R515a, R456a, ND, and R516a refrigerants used in the cooling system are determined per unit refrigerant. If the compressor speed values and the volumetric efficiency of the compressor are constant, the results of the effects of the refrigerants in the cooling system are compared with each other. When the system is operated with R445a, the highest COP value is obtained when the volumetric efficiency value is 0.7 . The R515a provided the closest COP value to $\mathrm{R} 134 \mathrm{a}$ when the compressor speed was $1750 \mathrm{rpm}$ and the $98 \%$ coefficient of performance value was similar. When the refrigerants considered are evaluated together, it was determined that R445a provides the best values according to R134a and has an average cooling capacity of approximately $12 \%$ is higher.
\end{abstract}

Keywords: Refrigerant, volumetric efficiency, R445a, R515a, R456a, ND, R516a

${ }^{1}$ Ümit İŞKAN (Orcid ID: 0000-0001-6236-2339), Yalova University, Institute of Science and Engineering, Energy Systems Engineering, Yalova, Turkey

${ }^{2}$ Mehmet DİREK (Orcid ID: 0000-0001-5868-6381), Fikret YÜKSEL (Orcid ID: 0000-0002-3670-4355), Cemil KOYUNOĞLU (Orcid ID: 0000-0001-6309-1569), Yalova University, Engineering Faculty, Energy Systems Engineering, Yalova, Turkey

*Sorumlu Yazar/Corresponding Author: Cemil KOYUNOĞLU, e-mail: cemikoy@gmail.com 


\section{INTRODUCTION}

The aim is to reduce the adverse effects of the refrigerants on the environment within various regulations and restrictions. The European Union's directive 517/2014 limits the GWP value (Regulation (EU) No 517/20, 2014). In the relevant directive, dates are determined for drawing the refrigerants with high GWP values and the limits to be used. Below, the features required from the refrigerant-related directive are shown in (Table 1) with historical limitations.

Table 1. Restrictions imposed by the European Union directive (Regulation (EU) No 517/20, 2014; Aricapa et al., 2020).

\begin{tabular}{llc}
\hline System & GWP & Banned date \\
\hline Freezers and home refrigerators & $\geq 150$ & $01 / 01 / 2015$ \\
Freezers and commercial refrigerators & $\geq 2500$ & $01 / 01 / 2020$ \\
Freezers and commercial refrigerators & $\geq 150$ & $01 / 01 / 2022$ \\
Specially produced for operating at $-50{ }^{\circ} \mathrm{C}$ of stationary coolers & $\geq 2500$ & $01 / 01 / 2020$ \\
Multiple compressor cooling systems, less than $40 \mathrm{~kW}$ & $\geq 150$ & $01 / 01 / 2022$ \\
First cycle external cycles in cascade cooling systems & $\geq 1500$ & $01 / 01 / 2022$ \\
Air conditioning systems in mobile & $\geq 150$ & $01 / 01 / 2020$ \\
Split air conditioning systems containing fluorinated gas, less than 3 kg & $\geq 750$ & $01 / 01 / 2025$ \\
\hline
\end{tabular}

Scientific and commercial studies are still underway towards realizing the use of low GWP but high-performance refrigerants instead of high GWP refrigerants in cooling systems, following the restrictions of the relevant directive (Regulation (EU) No 517/20, 2014). In these studies, researches are conducted on different combinations of HC, HFC, HFO, and R744 to improve the thermophysical properties of fluids with low GWP due to high performance (Abas et al., 2018; Azzolin et al., 2019; Aricapa et al., 2020; Makhnatch et al., 2017; Rasti et al., 2013).

R1234yf with low GWP value can be used in mobile air conditioning systems as an alternative to R134a. (Navarro-Esbrí et al., 2012; Babiloni et al., 2015; Sieres and Santos, 2014; Direk et al., 2017; Meng et al., 2018; Aral et al., 2020). Bayrakci et al. (2009) theoretically calculated the coefficients of performance (COP) and cooling capacities in the cooling cycle of propane, butane, isobutane, and isopentane with low GWP value. They also determined that the COP of butane and isopentane were higher than propane and butane. Cheng et al., (2017), the mixture obtained with R1234ze(E) tested refrigerant in the heat pump system. In their study, the effect of various ratios of R1234ze(E) concentration on the performance of heat pump systems was evaluated. Jemaa et al. (2018) investigated an R1234ze(E) vapor compression system. Due to the experiment's results of the study that R1234ze(E) irreversibility was lower than that of the system using R134a. Direk and Soylu (2018) also studied R1234ze(E) working with R134a in a vapor compression refrigeration system. $\mathrm{R} 1234 \mathrm{ze}(\mathrm{E})$ has a $27 \%$ lower cooling capacity than that of the system using R134a.

In their study in Guarav et al. (2018) made comparisons of the effect of R134a used in cooling systems on the performance of alternative different refrigerant mixtures. At the end of the study, they determined that the values closest to R134a were obtained from a mixture of $40 \% \mathrm{R} 134 \mathrm{a}, 22 \%$ R1234yf, and 38\% R1234ze(E). Direk et al. (2018) studied the total exergy destruction of the AAC system. Predicting the total exergy destruction, an empirical correlation was developed. It is obtained in the study that the maximum and minimum deviation was found that the R1234yf+IHX and R1234yf as $8.8 \%$ and $7.21 \%$.

As an alternative to R134a, Jian Sun and colleagues tested R516a in the vapor compression refrigeration system in 2019. They have seen that the compressor has the highest irreversibility value 
among the system equipment. As an alternative to R134a, R290, R600a, R407c, R410A, R404A, R152a, and R1234yf refrigerant was used. Vaghela (2017) theoretically evaluated the performance values obtained in the vapour compression refrigeration system. In their evaluation, they determined that the most suitable refrigerant was R1234yf instead of R134a. In their study in Kashif and his colleagues, (2017) tried R290 (propane) and R600a (isobutane) refrigerants as an alternative to R134a in a heat pump cycle used for water heating. According to their results, they stated that R290 gives a higher performance value than R600a, while R600a provides higher compressor capacity at the same heating capacity values. Sotomayor and Parise (2016) obtained the data which is compatible with the literature information used to develop a mathematical model for the R134a AAC system compressor. This model is applied to alternative refrigerants. It is found that the model they developed as R1234yf and R290. Babilioni et al. (2015) used R32, R125, R152a, R1234yf, R1234ze(E), and their mixture to suggest using each refrigerant individually and with mixture instead of refrigerant fluids with high GWP. Even though some of these mixes would result in security issues, other mixtures of these refrigerants could be used.

In our study, the performance of different refrigerants on the same system will be evaluated in consideration of the thermophysical properties. Also, evaluations were made in compressor cycles determined by Tian relation, which gives close values between $90 \%$ and $100 \%$ to real values (Tian et al., 2004). In the continuation of the study, the ratio of Tian correlation to sensitive values at different values was determined. R444a, R515a, R456a, ND, and R516a mixture refrigerants, whose properties are given in (Table 2), are determined as an alternative to R134a. In the same table, the thermophysical properties of the related refrigerants are seen.

Table 2. Alternative refrigerants thermophysical properties (Lemmon et al., 2014)

\begin{tabular}{lcccccc}
\hline Refrigerants & R134a & R515a & R456a & ND & R516a & R445a \\
\hline Refrigerants, in the mixture & - & R1234ze(E) & R32 & R134a & R1234yf & R134a \\
amounts of blending & & R227ea & R134a & R1234yf & R134a & R1234ze(E) \\
& & & R1234ze(E) & R1234ze(E) & R152a & R744 \\
\hline Percentages of mass $(\%)$ & - & $88 / 12$ & $6 / 45 / 49$ & $40 / 22 / 38$ & $77.5 / 8.5 / 14$ & $9 / 85 / 6$ \\
Mixtures critical pressure $(\mathrm{kPa})$ & 4059.3 & 3555.7 & 4175.2 & 3968.8 & 3615.2 & 4544.4 \\
Critical temperature $\left({ }^{\circ} \mathrm{C}\right)$ & 101.05 & 108.65 & 102.65 & 118.35 & 96.65 & 106.05 \\
$25^{\circ} \mathrm{C}$ steam density $\left(\mathrm{kg} \mathrm{m}{ }^{-3}\right)$ & 13.83 & 13.93 & 13.99 & 13.24 & 14.38 & 14.33 \\
Latent heat of vaporazation $(\mathrm{kJ} / \mathrm{kg})$ & 177.78 & 159.76 & 173.12 & 163.26 & 166.55 & 171.61 \\
GWP100 & 1300 & 387 & 687 & 522 & 131 & A2L \\
ASHRAE's security Class & A1 & A1 & A1 & A1 & A2L \\
\hline Data
\end{tabular}

Data obtained through REFPROP (Lemmon et al. 2014) to a temperature of $298.15 \mathrm{~K}$

\section{Theoretical Analysis}

Based on the classical mechanical vapour compression refrigeration cycle given in (Figure 1), data were obtained as a result of analysing R134a, R515a, R445a, ND, R456a, and R516a refrigerants using the (Tian et al., 2004) correlation obtained from the literature. In all operating conditions, the flow rate of the refrigerant circulating in the system was taken as $0.035 \mathrm{~kg} \mathrm{~s}^{-1}$. The evaporation (inlet to the evaporator) temperature of the refrigerant is $10^{\circ} \mathrm{C}$, and the total compressor internal volume is 138 $\mathrm{cm}^{3}$, the constant isentropic efficiency value $\left(\eta_{\text {is }}\right) 0.8$ is taken. Besides, changes in potential and kinetic energies were neglected during circulation. The compressor, expansion valve, and pipes are considered to be adiabatic, and the process of the refrigerant in the expansion valve is isentropic. 


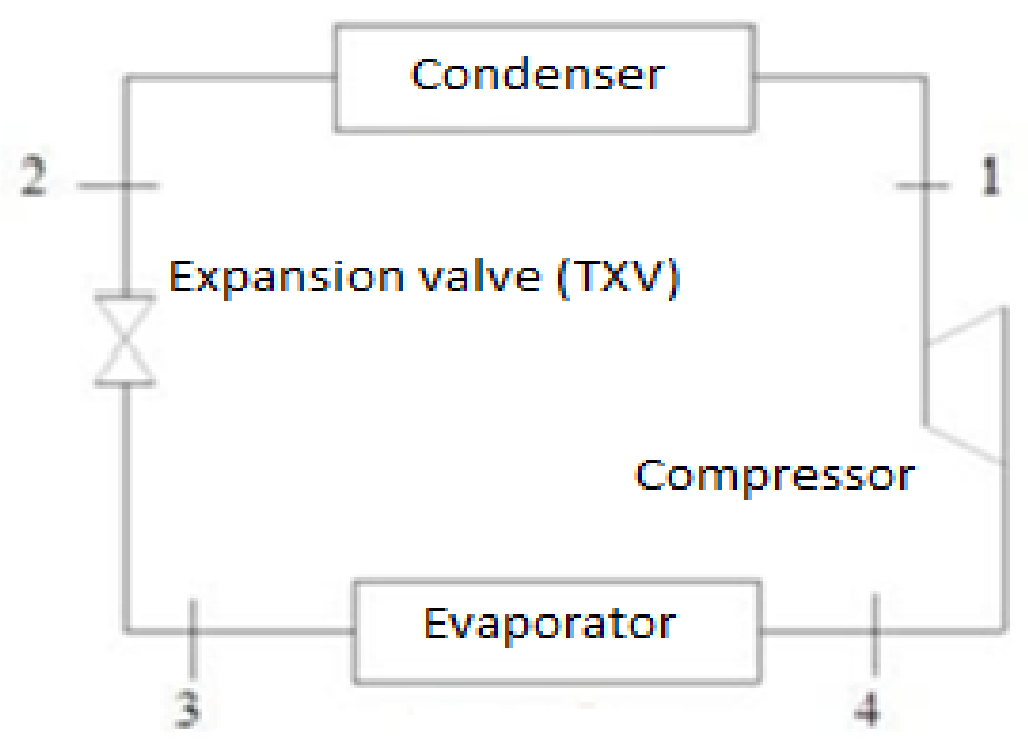

Figure 1. Mechanical vapour compression refrigeration cycle

\section{Thermodynamic Analysis}

The theoretical mass flow rate is determined using (Equation 1) for the vapour compression cooling system.

$\dot{m}_{r e f}=\rho_{\text {ref }} V_{G}(\mathrm{~N} / 60) \eta_{v}$

Tian et al. (2004) suggested the following relation in 2004 for the volumetric efficiency value. In this formula, volumetric efficiency is determined due to compressor speed and compression ratios and some limitations.

$$
\begin{aligned}
& \eta_{v}=1.81-0.35 \cdot \varepsilon+0.026 \cdot \varepsilon^{2}-0.00081 \cdot N_{c}+2 \cdot 51 \cdot 10^{-7} \cdot N_{c}^{2}+0.00026 \cdot \varepsilon \cdot N_{c} \\
& -2.07 \cdot 10^{-5} \cdot \varepsilon^{2} \cdot N_{c}-8.68 \cdot 10^{-8} \cdot \varepsilon \cdot N_{c}^{2}+7 \cdot 07 \cdot 10^{-9} * \varepsilon^{2} \cdot N_{c}^{2}
\end{aligned}
$$

(compressor compression ratio; $\varepsilon=3.6$ - 6.2; compressor speed; $N_{c}=900-3000$ RPM and Superheat value is $15^{\circ} \mathrm{C}$.)

Cooling capacities were found according to the equation below.

$$
\dot{Q}_{\text {evap }}=\dot{m}_{\text {ref }}\left(h_{\text {evap }, e}-h_{\text {evap }, i}\right)
$$

Compressor power is calculated using the equation below for the cycle.

$$
\dot{W}_{\text {comp }}=\dot{m}_{\text {ref }}\left(h_{\text {comp }, e}-h_{c o m p, i}\right)
$$

In (Equation 5), the COP value of the system is given.

COP $=\frac{\dot{Q}_{\text {evap }}}{\dot{W}_{\text {comp }}}$ 


\section{MATERIALS AND METHODS}

\section{Evaluation according to constant volumetric efficiency value}

In this method, compressor speeds from (Equation 1) for two different constant volumetric efficiency values $(0.7$ and 0.65$)$ were found using the densities of the refrigerants at $25^{\circ} \mathrm{C}$. Then, from (Equation 2), the compression ratios of fluids and evaporation pressures using the REFPROP program were found depending on the compressor speeds found (Lemmon et al., 2014). Finally, condensation pressures were calculated with the compression ratios and evaporation pressures obtained, and cycle points in the P-h diagram were created for the refrigerants considered, as shown in (Figure 2).

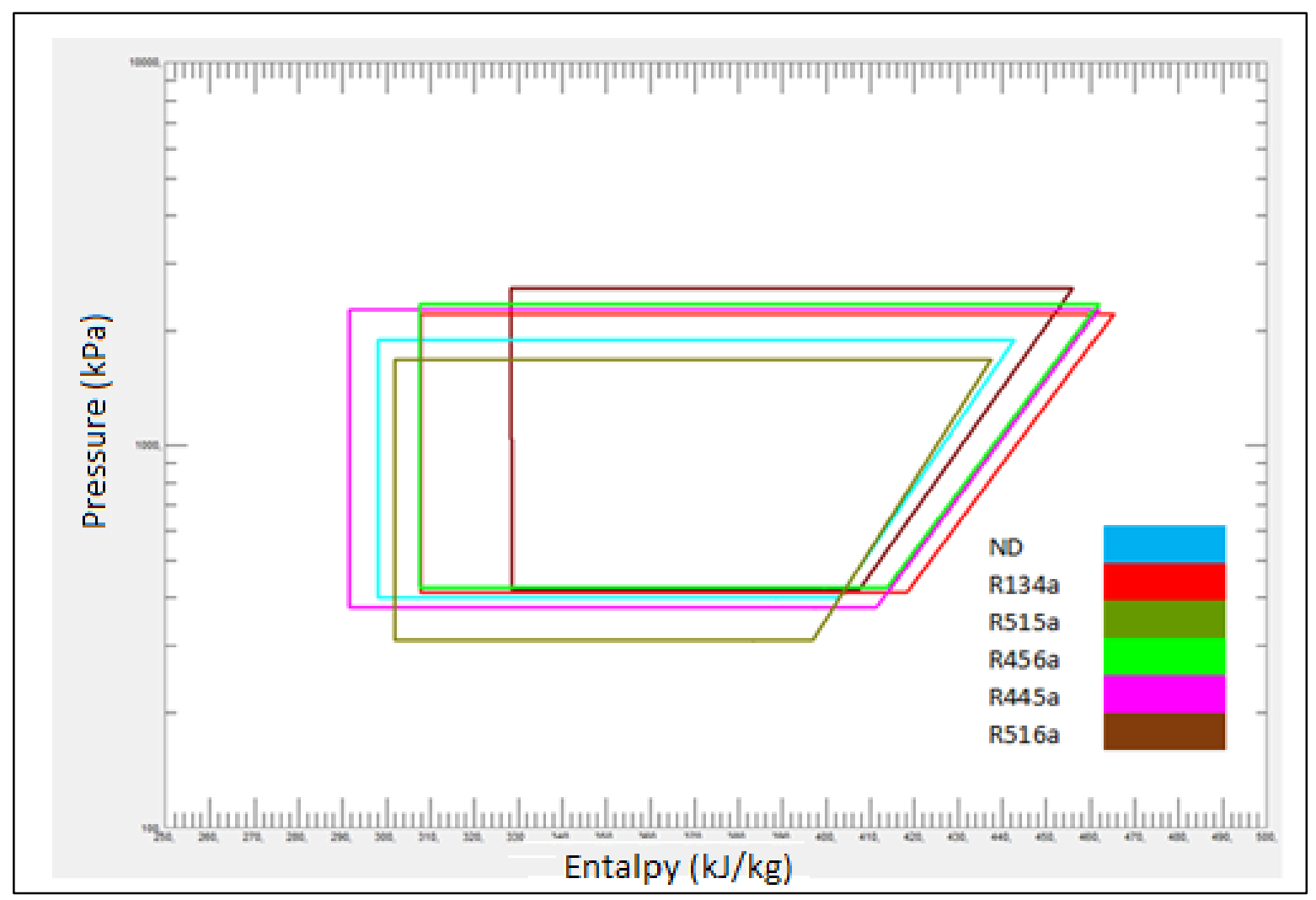

Figure 2. Created refrigeration cycles of all refrigerants used in the analysis with the REFPROP program

\section{Evaluation based on fixed compressor speed value}

Firstly, volumetric efficiency values were determined for fixed compressor speeds in the method of evaluating different refrigerants according to the constant compressor speed value by using the densities at $25{ }^{\circ} \mathrm{C}$ in the (Table 2). Using the compression ratios and REFPROP program from (Equation 2), the condensing pressures were calculated together with the volumetric efficiency values found. As seen in (Figure 2), the refrigeration cycle of the fluid on the P-h diagram is created. In (Figure 3-a), the constant volumetric efficiency method of the flow diagram and in (Figure 3-b), the flow diagram of the method made depending on the constant compressor speed can be seen. 


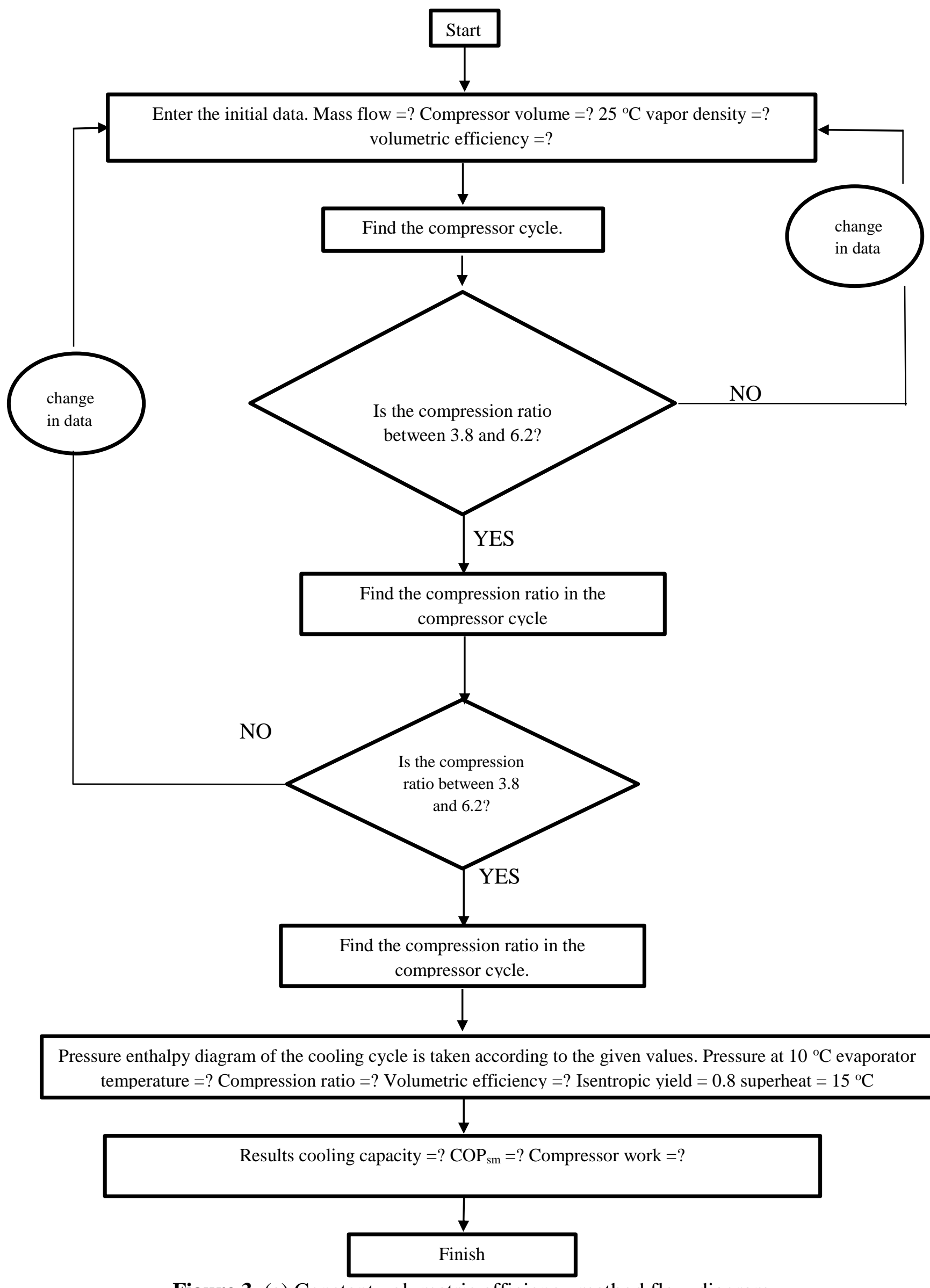

Figure 3. (a) Constant volumetric efficiency method flow diagram 
Volumetric Efficiency Evaluation of the Use of Refrigerants R445a, R515a, R456a, ND, and R516a with Low GWP Instead of R134a

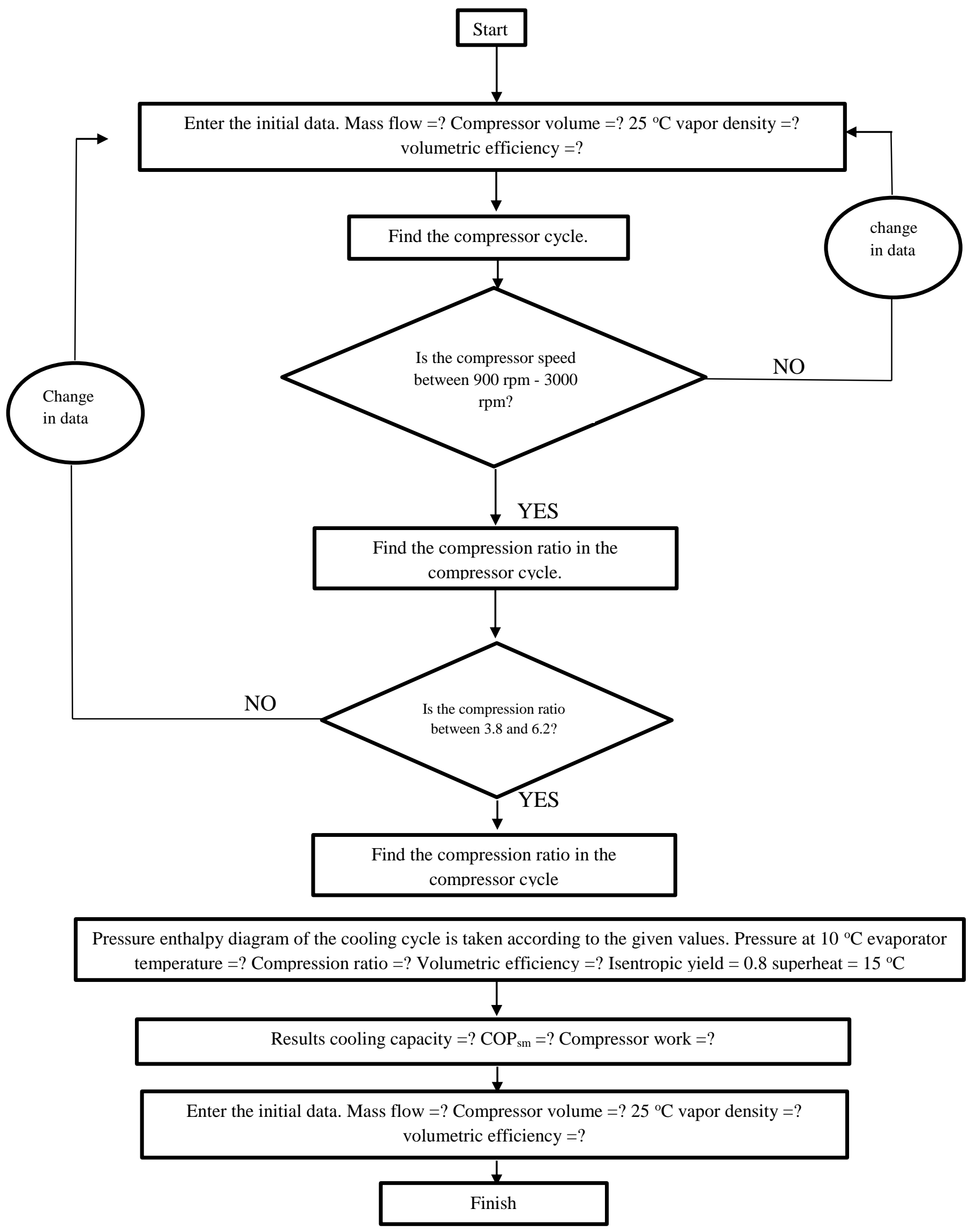

Figure 3. (b) Constant compressor speed flow diagram 


\section{RESULTS AND DISCUSSION}

Compression ratios obtained using (Equation 2) are given in (Table 3) for different refrigerants, which are taken into account at constant volumetric efficiency value (0.7). It can be examined in (Figure 4) in which revolutions of different refrigerants reach the same mass flow values $\left(0.035 \mathrm{~kg} \mathrm{~s}^{-1}\right)$ for constant volumetric efficiency $\left(\eta_{\mathrm{v}}\right)$ values. The same mass flow values $(0.65)$ were reached for all refrigerants evaluated at higher compressor speeds than the constant $\eta_{\mathrm{v}}$ value $\left(\eta_{\mathrm{v}}=0.7\right)$. However, the values obtained for refrigerants varied depending on the density values. While the system uses 700 $\mathrm{rpm}, \mathrm{R} 134 \mathrm{a}$ is used, and $\eta_{\mathrm{v}}$ is 0.7 , the mass flow rate of $0.035 \mathrm{~kg} \mathrm{~s}^{-1}$ is reached. When the R515a and $\mathrm{R} 456 \mathrm{a}$ values of $1670 \mathrm{rpm}$ were used, the same flow rates could be achieved.

Table 3. Compressor ratios and compression cycles calculated for a constant volumetric efficiency value

\begin{tabular}{lcc}
\hline Refrigerant & Volumetric efficiency (in \%) & Compression ratio \\
\hline R134a & 70 & 4.13 \\
R445a & 70 & 4.17 \\
R515a & 70 & 4.13 \\
R456a & 70 & 4.14 \\
ND & 70 & 4.08 \\
R516a & 70 & 4.16 \\
\hline
\end{tabular}

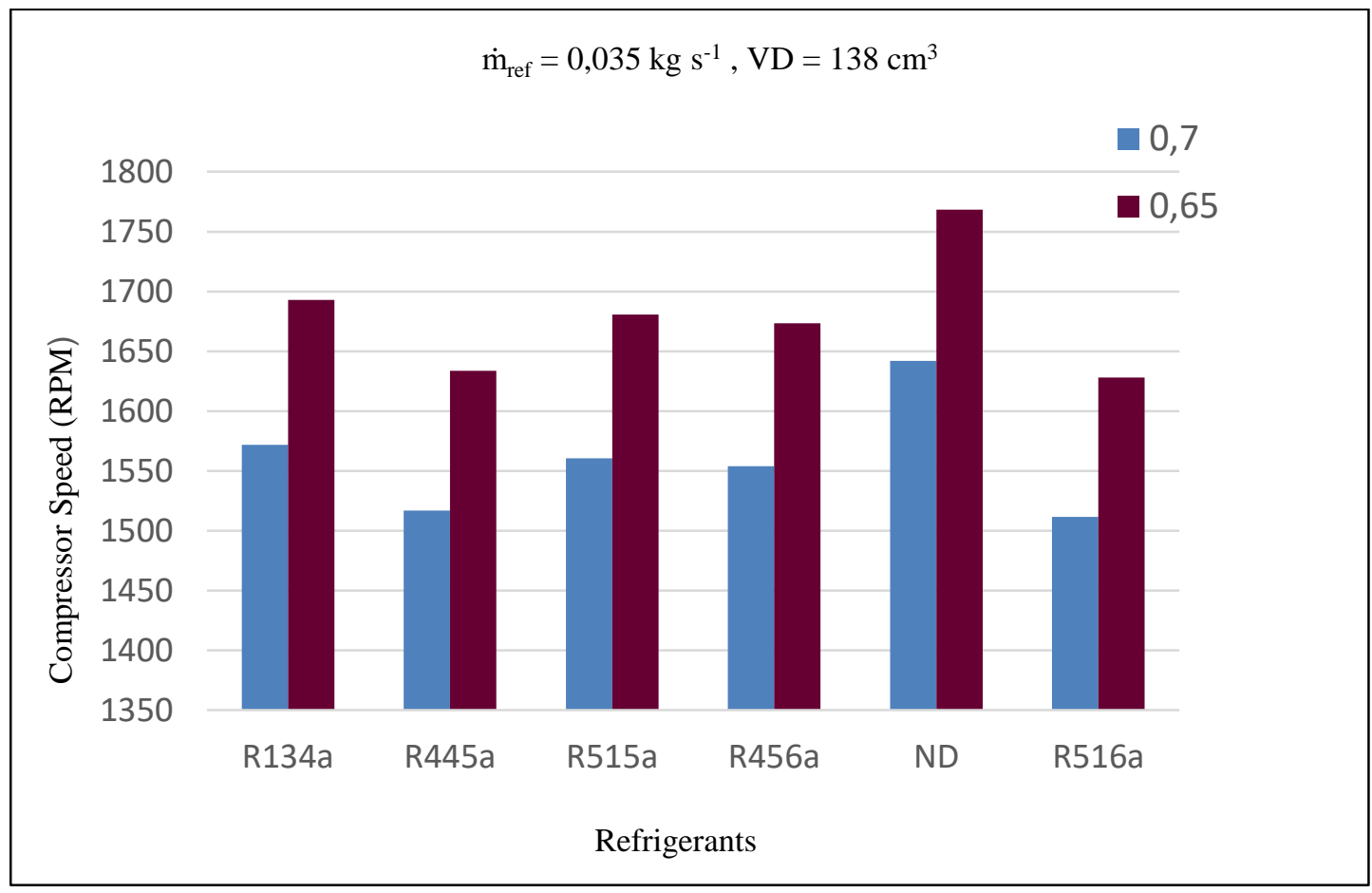

Figure 4. Compressor speeds obtained for different refrigerants by an evaluation based on constant volumetric efficiency values

In (Figure 5) a comparison of cooling capacities and COP values obtained from refrigerants taken into account in constant volumetric efficiency $\left(\eta_{\mathrm{v}}=0.7\right)$ is given. When (Figure 5) is examined, it is seen that the COP value and the highest cooling capacity are obtained when R445a is used as the refrigerant in the system. According to R456a and R515a, the COP value of R134a is 1\% and 2\% higher, respectively. COPs means the ratio of the cooling capacity obtained in the system to the power 
given to the refrigerant in the compressor. Due to the close cooling capacity of the compressor powers per unit refrigerant, the COP values of R456a and R515a are close to each other when (Figure 6) is examined. When the cooling capacities of R134a and R456a are evaluated for the same mass flow rates in the system, it is seen that they are very close to each other. This is because the latent heat of vaporization and vapor density values in both refrigerants for the unit mass is very close to each other. It can be said that the cooling capacities of R445a and R516a in the refrigerants evaluated for mobile air conditioning systems will be appropriate because they are close to R134a, and GWP values are below 150, respectively (Heredia-Aricapa et al. 2020).

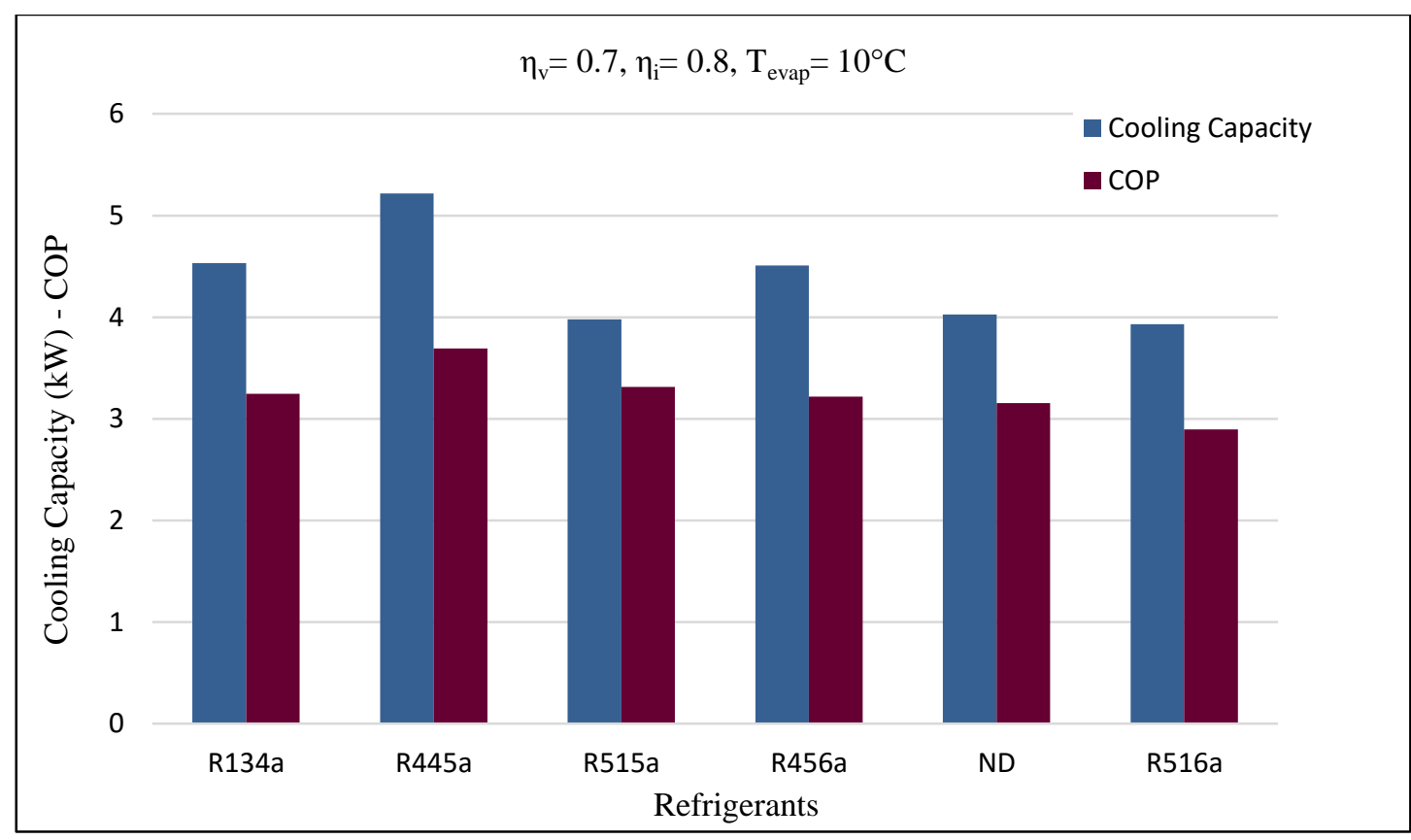

Figure 5. COP values and refrigeration capacities of refrigerants

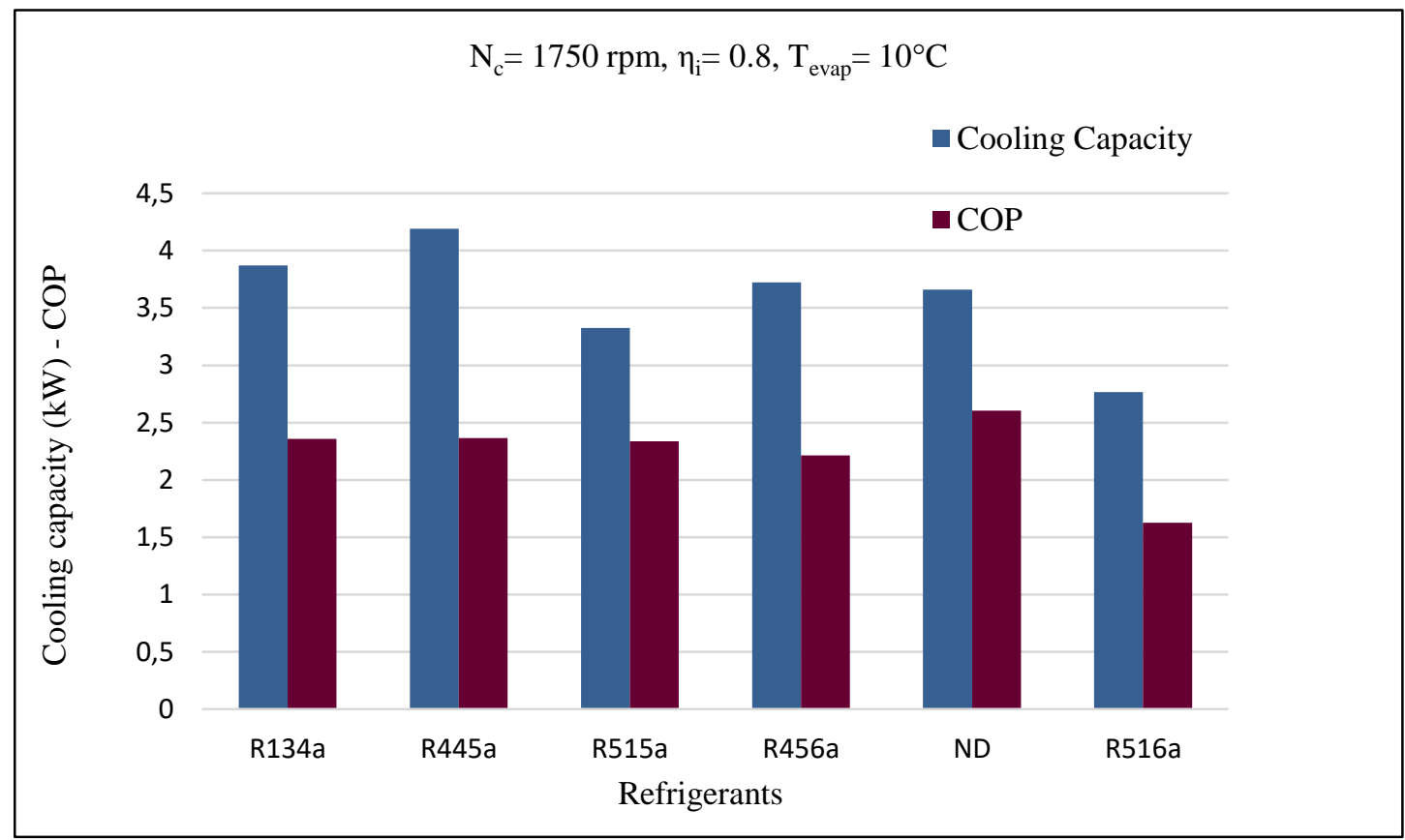

Figure 6. COP values and cooling capacities of refrigerants 
The efficiency and compression ratios obtained by applying (Equation 2) for a fixed compressor speed (1750 rpm) value of different refrigerants are given in (Table 4). When (Table 4) is examined, it is seen that the highest cooling capacity value is obtained when ND is used in the system depending on the critical temperature and pressure values by comparing the refrigerants for constant compressor speed in the system. As can be seen in (Figure 6), the cooling capacity of ND is 10\% more than R134a. When a fixed cycle compressor cycle. COP values were run with cycle R445a. It reached $1 \%$ close to R134a. In this context, when R445a is evaluated together with its environmental effects, it stands out in mobile air conditioning systems (Devecioğlu and Oruç, 2017).

Table 4. Volumetric efficiency and compression ratios in stationary compressor cycles

\begin{tabular}{lccc}
\hline Refrigerant & Compressor speed (RPM) & Volumetric efficiency (in \%) & Compression ratio \\
\hline R134a & 1750 & 62.87 & 5.33 \\
R445a & 1750 & 60.68 & 6.03 \\
R515a & 1750 & 62.42 & 5.45 \\
R456a & 1750 & 62.15 & 5.53 \\
ND & 1750 & 65.67 & 4.72 \\
R516a & 1750 & 60.47 & 6.13 \\
\hline
\end{tabular}

In the same period, although they have very close values to R456a, ND, and R134a, they are above 150 as GWP value and can be evaluated in other applications except for mobile systems (Heredia-Aricapa et al. 2020). R445a seems to be suitable for mobile air conditioning systems, both in terms of having a low GWP value and giving values close to R134a. However, since it contains a small amount of $\mathrm{CO}_{2}$, it has high pressure and necessary safety precautions must be taken in its use. Preliminary analyses were carried out with this theoretical study. The refrigerants approved for the replacement of R134a should also be tested experimentally, and their effect on the compressor oil used should be determined.

\section{CONCLUSION}

The closest cooling capacity and COP value to R134a were obtained as a result of the analyses and evaluations. When R445a and R515a were used in the system, the cooling capacity and COP values obtained in $\mathrm{R} 445 \mathrm{a}$ are $8.2 \%$ and $0.04 \%$ higher than $\mathrm{R} 134 \mathrm{a}$, respectively. The cooling capacities of R516a will be appropriate for mobile air conditioning systems because of the low GWP values. According to R456a and R515a, the COP value of R134a is $1 \%$ and 2\% higher, respectively.

In the same period, although they have very close values to R456a, ND, and R134a, they are above 150 as GWP value and can be evaluated in other applications except for mobile systems. R445a seems to be suitable for mobile air conditioning systems, both in terms of having a low GWP value and giving values close to R134a. However, since it contains a small amount of $\mathrm{CO}_{2}$, it has high pressure and necessary safety precautions must be taken in its use. Preliminary analyses were carried out with this theoretical study. The refrigerants approved for the replacement of R134a should also be tested experimentally, and their effect on the compressor oil used should be determined. 


\section{NOMENCLATURE}

$\begin{array}{ll}\text { GWP } & \text { General Warming Potential } \\ \text { GWP } 100 & \text { General Warming Potential for a hundred year } \\ \dot{Q} & \text { Heat transfer, }[\mathrm{kW}] \\ \dot{W} & \text { Work, }[\mathrm{kW}] \\ \mathrm{COP} & \text { Coefficient of Performance } \\ \dot{m} & \text { Mass flow rate, }\left[\mathrm{kg} \cdot \mathrm{s}^{-1}\right] \\ \mathrm{h} & \text { Enthalpy, }\left[\mathrm{kJ} \cdot \mathrm{kg}^{-1}\right] \\ \mathrm{T} & \text { Temperature, }\left[{ }^{\circ} \mathrm{C}\right] \\ \mathrm{N}_{\mathrm{c}} & \text { Compressor Speed }[\mathrm{RPM}] \\ \varepsilon & \text { Compressor Ratio } \\ \eta_{\mathrm{v}} & \text { Volumetric Efficiency } \\ \eta_{\mathrm{i}} & \text { Isentropic Efficiency } \\ \text { comp } & \text { Compressor, } \\ \text { cond } & \text { Condenser, } \\ \text { evap } & \text { Evaporator, } \\ \mathrm{i} & \text { Inlet, } \\ \mathrm{e} & \text { Outlet, } \\ \text { ref } & \text { Refrigerant, }\end{array}$

\section{REFERENCES}

Abas N, Kalair AR, Khan N, Haider A, Saleem Z, Saleem MS, 2018. Natural and synthetic refrigerants, global warming: a review, Renewable Sustain Energy Reviews 90: 557-569.

Aral MC, Suhermanto M, Hosoz M, 2020. Performance evaluation of an automotive air conditioning and heat pump system using R1234yf and R134a, Science and Technology for the Built Environment DOI: 10.1080/23744731.2020.1776067.

Azzolin M, Berto A, Bortolin S, Moro L, Del Col D, 2019. Condensation of ternary low GWP zeotropic mixtures inside channels, International Journal of Refrigeration 103: 77-90.

Bayrakçı HA, Özgür E, 2009. Energy and exergy analysis of vapor compression refrigeration system using pure hydrocarbon refrigerants, International Journal of Energy Research International Journal Energy Research 33: $1070-1075$.

Cheng Z, Wang B, Shi W, Li X, 2017. Numerical research on R32/R1234ze(E) air source heat pump under variable mass concentration, International Journal of Refrigeration, 82: 1-10.

Devecioğlu A. G, Oruç V, 2017. An analysis on the comparison of low-GWP refrigerants to alternatively use in mobile air-conditioning systems, Thermal Science and Engineering Progress, 1: 1-5.

Direk M, Mert MS, Yüksel F, Keleşoğlu A, 2018. Exergetic investigation of a R1234yf automotive air conditioning system with internal heat exchanger, International Journal of Thermodynamics 21,2: 103109

Direk M, Soylu E, 2018. The effect of internal heat exchanger using R1234ze(E) as an alternative refrigerant in a mobile air-conditioning system, Strojniški vestnik - Journal of Mechanical Engineering, 64: 114-120.

Direk M, Kelesoglu A, Akin A, 2017. Drop-in performance analysis and effect of IHX for an automotive air conditioning system with R1234yf as a replacement of R134a. Strojniški vestnik-Journal of Mechanical Engineering, 63: 5, 314-319. 
European Parliament and the Council, 2014. No 517/2014 of the European Parliament and of the Council of 16 April 2014 on fluorinated greenhouse gases and repealing regulation (EC). No 842/2006 text with EEA relevance. Off. J. Eur. Union L 150/195-230.

Gaurav G, Kumar R, 2018. Computational energy and exergy analysis of R134a. R1234yf. R1234ze and their mixtures in vapour compression system, Ain Shams Engineering Journal, 9: 3229-3237.

Heredia-Aricapa Y, Belman-Flores JM, Mota-Babiloni A, Serrano-Arellano J, García-Pabón JJ, 2020. Overview of low GWP mixtures for the replacement of HFC refrigerants: R134a. R404A and R410A, International Journal of Refrigeration, 111: 113-123.

Jemaa RB, Mansouri R, Boukholda I, Bellagi A, 2017. Energy and exergy investigation of R1234ze as R134a replacement in vapor compression chillers, International Journal of Hydrogen Energy 42, no. 17: $12877-12887$.

Lemmon EW, Huber ML, McLinden MO, 2013. NIST Standard Reference Database 23, NIST Reference Fluid Thermodynamic and Transport Properties. REFPROP version 10.0.

Meng Z, Zhang H, Lei M, Qin Y, Qiu J, 2018. Performance of low GWP R1234yf/R134a mixture as a replacement for R134a in automotive air condi- tioning systems. Int. J. Heat Mass. Transfer. 116: 362370.

Makhnatch P, Babiloni MA, Rogstam J, Khodabandeh R, 2017. Retrofit of lower GWP alternative R449A into an existing R404A indirect supermarket refrigeration system, International Journal of Refrigeration 76, 184-192.

Babiloni MA, Navarro-Esbrí J, Barragán-Cervera Á, Molés F, Peris B, 2015. Analysis based on EU Regulation No 517/2014 of new HFC/HFO mixtures as alternatives of high GWP refrigerants in refrigeration and HVAC systems, International Journal of Refrigeration 52: 21-31.

Navarro-Esbrí J, Mendoza-Miranda, JM, Mota-Babiloni A, Barragán-Cervera A, Belman-Flores JM, 2012. Experimental analysis of R1234yf as a drop-in replacement for R134a in a vapour compression system, International Journal of Refrigeration, 36, 3: 870-880,

Paul Ortega S, José Alberto Reis P, 2016. Characterization and simulation of an open piston compressor for application on automotive air-conditioning systems operating with R134a, R1234yf and R290, International Journal of Refrigeration, 61: 100-116.

RastiM, Aghamiri S, Hatamipour MS, 2013. Energy efficiency enhancement of a domestic refrigerator using R436A and R600a as alternative refrigerants to R134a. International Journal of Thermal Science, 74: 8694.

Sánchez D, Cabello R, Llopis R, Arauzo I, Catalán-Gil J, Torrella E, 2017. Energy performance evaluation of R1234yf. R1234ze(E). R600a. R290 and R152a as low-GWP R134 alternatives, International Journal of Refrigeration 74: 269-282.

Sieres J, Santos JM, 2018. Experimental analysis of R1234yf as a drop-in replacement for R134a in a small power refrigerating system, International Journal og Refrigeration, 9: 230-238.

Sun J, Li W, Cui B, 2020. Energy and exergy analyses of R513aas a R134a drop-in replacement in a vapor compression refrigeration system, International Journal of Refrigeration, 112: 348-356.

Tian C, Dou C, Yang X, Li X. 2004. A mathematical model of variable displacement wobbleb plate compressor for automotive air conditioning system, Applied Thermal Engineering, 24: 2467-2486.

Vaghela JK, 2017. Comparative evaluation of an automobile air-conditioning system using R134a and its alternative refrigerants, Energy Procedia, 109: 153-160. 